\title{
Relationships Between Selected Climatic Factors in Fattening Units and their Influence on the Development of Respiratory Diseases in Swine
}

\author{
By P. Beskow ${ }^{1}$, M. Norqvist ${ }^{1}$ and $P$. Wallgren ${ }^{2}$ \\ ${ }^{1}$ Swedish Animal Health Service, Vännäs, and ${ }^{2}$ National Veterinary Institute, Uppsala, Sweden.
}

\begin{abstract}
Beskow P, Norqvist M, Wallgren P: Relationships between selected climatic factors in fattening units and their influence on the development of respiratory diseases in swine. Acta vet. scand. 1998, 39, 49-60. - The correlation between climatic parameters with one another in fattening units and the influence of environmental factors on lung lesions registered at slaughter were studied in 6 integrated herds with continuous production systems. In addition, the influence of environmental parameters on the spread of Mycoplasma hyopneumoniae and Actinobacillus pleuropneumoniae (serotypes 2 and 3 ) and on the productivity was monitored in 2 specialized fattening herds with strict batch production.

The outdoor temperature was positively correlated to the indoor temperature, but negatively correlated to the relative humidity and the concentration of carbon dioxide in the stables. These indoor parameters were also correlated to each other. The concentration of ammonia was not correlated to any other climatic parameter.

No correlation between the climatic parameters measured and the prevalences of pneumonia and pleuritis registered at slaughter was shown. The rapidness in spread of mycoplasmosis seemed to be more dependent of the antibody status of the pigs on arrival than on the climate of the units. In contrast, a correlation between the climatic parameters and the spread of the less contagious infection (Actinobacillus) was indicated. The influence of the climatic parameters on the daily weight gain was not ensured.
\end{abstract}

pig; climate; lung lesions; growth rate; Mycoplasma hyopneumoniae; Actinobacillus pleuropneumoniae.

\section{Introduction}

Infections caused by Mycoplasma hyopneumoniae (M.hyopneumoniae) and Actinobacillus pleuropneumoniae (A.pp.) are common within modern swine production. These bacteria are primary pathogens (Nicolet 1992, Ross 1992) and cause severe financial losses for swine producers (Straw et al. 1990, Christensen \& Mousing 1992).

Poor indoor climate and environment have been reported to enhance the risk for respiratory diseases (Tielen \& Elbers 1988, Donham 1991, Robertson 1993). Consequently, heavy de- mands are made upon the ventilation systems in stables for swine, especially in countries with large temperature differences over the year and between days and nights.

In Sweden, infections with M.hyo. and A.pp. serotypes 2 and 3 are common in the fattening herds (Beskow et al. 1993, Wallgren et al. 1994). These infections are mostly of chronic and/or subclinical character. Despite a low mortality, these infections often cause large economic losses through impaired daily weight gain and feed conversion (Lundeheim 1988). 
Climatic disturbances have frequently been reported in herds located in the northern part of Sweden, and high prevalences of lung lesions caused by M.hyo. and A.pp. have been registered at slaughter in pigs from such herds. In some of the herds with poor indoor environmental climate, improvements causing reduced concentrations of ammonia and dust have decreased the prevalences of pneumonia and pleuritis registered at slaughter (Beskow et al. 1991, Gustafsson et al. 1994).

The aim of the present study was to monitor the influence of outdoor temperature on selected parameters reflecting the indoor climate as well as to monitor the influence of these indoor parameters on development of antibodies to M.hyo. and A.pp., the prevalence of lung lesions registered at slaughter and on weight gain.

\section{Materials and methods}

\section{Herds}

In the first investigation (Investigation I) 6 farrow to finish herds were studied. All herds performed continuous production systems, but had different prevalences of lung lesions registered at slaughter. Herds $\mathrm{A}$ and $\mathrm{B}$ had elevated prevalences of pleuritis $(>25 \%)$, and herd $C$ elevated prevalence of pneumonia ( $>25 \%$ ) registered at slaughter. The remaining 3 herds (D-F) had low prevalences of pneumonia and pleuritis registered at slaughter $(<5 \%$ of each lung lesion). For technical description of the fattening units, including the ventilation systems, see Table 1.

Two of the herds (A and F) had weaning units in which weaned pigs were kept until the age of 12-13 weeks before transfer to the fattening units. In these herds, the pigs were reared in the finishing units from $25-30 \mathrm{~kg}$ to $108 \mathrm{~kg}$ body weight. In the herds without weaning units (herds B-E), the pigs were reared in the fattening units from $20 \mathrm{~kg}$ to $108 \mathrm{~kg}$ body weight. All herds had some form of heating system and used cutter shavings (only or together with straw) in the pens. Wet feed (milk productions and grain) was given to the fatteners in all herds, except for herd $\mathrm{C}$ in which the animals were given a dry feed.

In the second investigation (Investigation II), 2 specialized fattening herds performing strict batch production (all in, all out) and rearing pigs from 22 to $107 \mathrm{~kg}$ body weight were studied. Both herds had a high daily weight gain (DWG), >750 gram per day. Herd G had an elevated prevalence $(>20 \%)$ of pneumonia registered at slaughter while the prevalence of pneumonia was lower $(<15 \%)$ for herd H. For both herds, the prevalence of pleuritis was less than 6\% (Table 2).

Herd $\mathrm{G}$ produced 485 pigs per batch in a conventional fattening unit with 4 rows of pens. Eight to 9 fattening pigs were housed in each pen. The floor in the pens were solid, while the dunging area consisted of slatted floor. The ventilation system consisted of 40 commercial slotted inlets along the long side walls and the air was evacuated by 4 fans in the ceiling over the middle passage and 6 gas exhaust outlets below slatted floors. A heating system was used on arrival and during the winter season. The pigs were fed a dry diet, mainly home produced grain and hay. Straw was given to the pigs in the pens every day.

Herd $\mathrm{H}$ was housing 230 pigs in a conventional fattening unit in 2 rows of pens with 11 to 12 pigs in each pen. Like herd $G$, the floor in the pens was solid and the dunging areas had slatted floor. The ventilation system consisted of 26 commercial slotted inlets along the long side walls and air was evacuated by 2 fans in the ceiling over the slatted floor and by 1 fan at 1 of the gables. The heating system was mainly used at time for arrival of pigs to the fattening unit. The pigs were given wet feed (milk productions and grain) and straw was provided daily. 
Table 1. Technical description of the fattening units in herds A-F.

\begin{tabular}{|c|c|c|c|c|c|c|}
\hline \multirow[b]{2}{*}{ Herd } & \multicolumn{3}{|c|}{ Number of } & \multirow[b]{2}{*}{ Air inlets } & \multirow[b]{2}{*}{ Air evacuations } & \multirow{2}{*}{$\begin{array}{c}\text { Presence of } \\
\text { gas haust } \\
\text { outlets** }\end{array}$} \\
\hline & $\begin{array}{l}\text { fattening } \\
\text { units }\end{array}$ & $\begin{array}{c}\text { pens } \\
\text { per unit }\end{array}$ & $\begin{array}{l}\text { fatteners } \\
\text { per unit }\end{array}$ & & & \\
\hline A & $2 *$ & 22 & 220 & $\begin{array}{l}\text { Textile tubes in the } \\
\text { ceiling over the pens }\end{array}$ & $\begin{array}{l}\text { Fans in the ceiling } \\
\text { and in the manure } \\
\text { channel }\end{array}$ & No \\
\hline B & 1 & 36 & 324 & $\begin{array}{l}\text { Concentrated recircula- } \\
\text { tion inlets in the ceiling } \\
\text { in the middle of the stable }\end{array}$ & $\begin{array}{l}\text { Fans in one of the } \\
\text { gables and in the } \\
\text { manure channel }\end{array}$ & Yes \\
\hline $\mathrm{C}$ & 1 & 22 & 176 & $\begin{array}{l}\text { Slotted inlets in the } \\
\text { ceiling over the manure } \\
\text { channel }\end{array}$ & Fans in the ceiling & Yes \\
\hline $\mathrm{D}$ & 1 & 50 & 450 & $\begin{array}{l}\text { Slotted inlets in the } \\
\text { ceiling over the pens }\end{array}$ & Fans in the ceiling & No \\
\hline $\mathrm{E}$ & $2 *$ & 24 & 216 & $\begin{array}{l}\text { Breathing ceiling over } \\
\text { the pens }\end{array}$ & $\begin{array}{l}\text { Fans in the ceiling } \\
\text { and in the manure } \\
\text { channel }\end{array}$ & No \\
\hline F & $2 *$ & 22 & 198 & $\begin{array}{l}\text { Textile tubes in the } \\
\text { ceiling over the pens }\end{array}$ & Fans in the ceiling & No \\
\hline
\end{tabular}

* Identical units. $\quad * *$ Located below slatted floor in the dunging area.

\section{Design of the investigations}

Investigation I (herds A-F) was aimed to monitor correlation between outdoor and indoor climates and correlation between indoor climate and lung lesions registered at slaughter. The indoor environmental parameters (see below) were registered in 3 pens (gable, middle and gable) per fattening unit. In herds with 2 fattening units, both units were investigated. The outdoor parameter (temperature) was measured outside the stables. With a view to understanding the seasons' influence of the indoor climates, all measurements were recorded on 6 occasions per herd, spread over the year: February, March, May, June, October and November.

In Investigation II (herds $G$ and $H$ ), the main aim was to analyse correlations between the indoor climate and the development of antibodies to M.hyo. and A.pp. as well as the productivity (DWG) of the herds. The study of herd $G$ was initiated at the beginning of April and ended in July, while the study of herd $\mathrm{H}$ was initiated at the end of January and ended in May the same year.

In herds $\mathrm{G}$ and $\mathrm{H}, 40$ pigs per each herd randomly selected from 10 pens were blood sampled on arrival. The pens were evenly distributed within the herds. The principals were blood sampled every third week and the sera were analysed for presence of antibodies to M.hyo. and A.pp. serotypes 2 and 3. Simultaneously, the environmental factors were registered in 3 pens (gable, middle and gable) in each row 
Table 2. The average of lung lesions registered at slaughter and daily weight gain (DWG) in herds G and $\mathrm{H}$ before and during the investigation.

\begin{tabular}{lcccccccc}
\hline & \multicolumn{3}{c}{ Before the investigation } & & \multicolumn{3}{c}{ During the investigation } \\
\cline { 2 - 3 } & Herd G & Herd $\mathrm{H}$ & Sign. & & Herd G & Herd $\mathrm{H}$ & Sign. \\
\hline No of pigs & 1938 & 1114 & & & 470 & 228 & \\
No. of observations & 4 & 5 & & & 1 & 1 & \\
Pneumonia (\%) & 21.1 & 11.7 & $*$ & & 15.0 & 13.7 & N.S. \\
Pleuritis (\%) & 5.2 & 3.9 & N.S. & & 2.1 & 2.2 & N.S. \\
DWG (g/day) & 833 & 793 & $*$ & & 788 & 734 & $*$ \\
\hline
\end{tabular}

N.S. $=$ Not significant. $\quad *=p<0.05$.

of pens. Thus, these parameters were registered in 6 pens of herd $G$ and in 3 pens in herd $H$. Information on DWG in herds $\mathrm{G}$ and $\mathrm{H}$ was obtained by an efficiency control scheme (Result Analysis for Swine Production, RASP II).

In both investigations, the prevalences of pathological lesions at slaughter were registered according to the rules issued by the Swedish Food Administration (1990).

\section{Analyses of environmental factors}

The outdoor temperatures were registered about $1.0 \mathrm{~m}$ above the ground 5-10 meters outside the stables with a thermometer of a psychrometer (Wilh. Lambrecht Gmbh, Göttingen, Germany).

The concentrations of carbon dioxide, indoor temperature and relative humidity were measured about $0.5 \mathrm{~m}$ above the solid floor in the pens, while the concentration of ammonia was measured $0.5 \mathrm{~m}$ above the slatted floor of the manure channel. For the gas measurements, a gas detector (Kitagawa, Komyo Rikagaku Kogyo K.K., Tokyo, Japan) was used and for the measurements of temperature and relative humidity, a psychrometer (Wilh. Lambrecht Gmbh, Göttingen, Germany) was used.

Blood sampling and detection of antibodies to M.hyo. and A.pp.

In herds $\mathrm{G}$ and $\mathrm{H}$, the pigs were blood sampled without additives by jugular vein punctures (Becton Dickinson Vacutainer Systems Europe, Meylan-Cedex, France) and sera were analysed for presence of antibodies to M.hyo. and A.pp. serotypes 2 and 3.

Detection of antibodies to M.hyo. was measured in sera (diluted 1:100) using an indirect ELISA based on a tween 20 treated antigen (Bölske et al. 1990, Wallgren et al. 1992). Absorbance levels above $\mathrm{A}_{450}=0.5$ were considered positive.

Detection of antibodies to A.pp. serotypes 2 and 3 , were measured in sera (diluted 1:1000) using an indirect ELISA with phenol water extracted antigens (Hurvell et al. 1983, Wallgren et al. 1994). Absorbance levels above $A_{450}=0.3$ were considered positive.

\section{Statistical analysis}

Statistical differences between mean values were calculated with Mann-Whitney U tests. Spearman rank correlations between climatic factors were calculated using the SAS programme package (SAS Institute Inc, 1988). Calculations regarding prevalence of seropositive animals were performed by chi-square tests.

\section{Results}

Investigation I (Herds $A-F$ )

The mean values of the outdoor and indoor pa- 
Table 3. The average outdoor temperature, selected indoor climatic parameters and the prevalences of pneumonia and pleuritis registered at slaughter in herds A-F over the year.

Winter climatic measures: Feb.-March. Abattoir registrations: Feb.-April.

\begin{tabular}{|c|c|c|c|c|c|c|c|c|}
\hline \multirow[b]{2}{*}{ Herds } & \multirow{2}{*}{$\begin{array}{l}\text { Outdoor } \\
\text { temp. } \\
\text { deg. C. }\end{array}$} & \multicolumn{4}{|c|}{ Indoor } & \multicolumn{3}{|c|}{ Registered at slaughter } \\
\hline & & $\begin{array}{l}\text { temp. } \\
\text { deg. C. }\end{array}$ & $\begin{array}{c}\text { rel.hum. } \\
\%\end{array}$ & $\begin{array}{l}\mathrm{CO}_{2} \\
\text { ppm }\end{array}$ & $\begin{array}{l}\mathrm{NH}_{3} \\
\mathrm{ppm}\end{array}$ & $\begin{array}{c}\text { Pigs } \\
\text { no. }\end{array}$ & $\begin{array}{c}\text { Pneum. } \\
\%\end{array}$ & $\begin{array}{c}\text { Pleuritis } \\
\%\end{array}$ \\
\hline A & -7 & 17 & 81 & 3375 & 4 & 331 & 4.8 & 26.0 \\
\hline B & -13 & 16 & 78 & 2783 & 4 & 252 & 2.8 & 19.8 \\
\hline $\mathrm{C}$ & -15 & 13 & 80 & 2917 & 9 & 121 & 10.7 & 5.8 \\
\hline D & -15 & 12 & 88 & 3717 & 3 & 178 & 2.2 & 9.6 \\
\hline $\mathrm{E}$ & -11 & 16 & 81 & 3975 & 9 & 278 & 2.2 & 2.5 \\
\hline $\mathrm{F}$ & -9 & 17 & 82 & 4050 & 11 & 239 & 1.6 & 1.7 \\
\hline Mean & -11.7 & 15.2 & 81.7 & 3469.5 & 6.7 & - & 4.1 & 10.9 \\
\hline
\end{tabular}

Spring climatic measures: May-June. Abattoir registrations: May-July.

\begin{tabular}{|c|c|c|c|c|c|c|c|c|}
\hline \multirow[b]{2}{*}{ Herds } & \multirow{2}{*}{$\begin{array}{c}\text { Outdoor } \\
\text { temp. } \\
\text { deg.C. }\end{array}$} & \multicolumn{4}{|c|}{ Indoor } & \multicolumn{3}{|c|}{ Registered at slaughter } \\
\hline & & $\begin{array}{l}\text { temp. } \\
\text { deg.C. }\end{array}$ & $\begin{array}{c}\text { rel.hum } \\
\%\end{array}$ & $\begin{array}{l}\mathrm{CO}_{2} \\
\mathrm{ppm}\end{array}$ & $\begin{array}{l}\mathrm{NH}_{3} \\
\mathrm{ppm}\end{array}$ & $\begin{array}{c}\text { Pigs } \\
\text { no. }\end{array}$ & $\begin{array}{c}\text { Pneum. } \\
\%\end{array}$ & $\begin{array}{c}\text { Pleuritis } \\
\%\end{array}$ \\
\hline A & 15 & 22 & 71 & 1600 & 4 & 364 & 5.8 & 29.4 \\
\hline B & 18 & 21 & 65 & 1067 & 3 & 259 & 1.9 & 28.2 \\
\hline C & 17 & 21 & 68 & 1600 & 9 & 107 & 24.3 & 3.7 \\
\hline D & 20 & 23 & 72 & 1650 & 7 & 147 & 2.7 & 11.6 \\
\hline E & 19 & 23 & 65 & 2108 & 6 & 313 & 3.2 & 4.8 \\
\hline F & 18 & 23 & 68 & 1767 & 7 & 299 & 2.0 & 5.7 \\
\hline Mean & 17.8 & 22.2 & 68.2 & 1632.0 & 6.0 & - & 6.7 & 13.9 \\
\hline
\end{tabular}

Autumn climatic measures: Oct.-Nov. Abattoir registrations: Oct.-Dec.

\begin{tabular}{lccccccccc}
\hline & \multirow{2}{*}{$\begin{array}{c}\text { Outdoor } \\
\text { temp. } \\
\text { Heg.C. }\end{array}$} & $\begin{array}{c}\text { temp. } \\
\text { deg.C. }\end{array}$ & $\begin{array}{c}\text { rel.hum. } \\
\%\end{array}$ & $\begin{array}{l}\mathrm{CO}_{2} \\
\mathrm{ppm}\end{array}$ & $\begin{array}{c}\mathrm{NH}_{3} \\
\mathrm{ppm}\end{array}$ & & $\begin{array}{c}\text { Pigs } \\
\text { no. }\end{array}$ & $\begin{array}{c}\text { Pneum. } \\
\%\end{array}$ & $\begin{array}{c}\text { Pleuritis } \\
\%\end{array}$ \\
\hline $\mathrm{A}$ & 0 & 18 & 80 & 3050 & 3 & & 390 & 7.7 & 26.2 \\
$\mathrm{~B}$ & 0 & 19 & 78 & 3533 & 4 & & 324 & 2.2 & 22.5 \\
$\mathrm{C}$ & -4 & 16 & 73 & 2600 & 8 & & 66 & 22.7 & 4.5 \\
$\mathrm{D}$ & -1 & 14 & 83 & 2533 & 3 & & 144 & 2.8 & 5.6 \\
$\mathrm{E}$ & -1 & 16 & 79 & 2467 & 7 & & 352 & 2.0 & 3.7 \\
$\mathrm{~F}$ & -1 & 19 & 80 & 3258 & 12 & & 249 & 4.8 & 1.6 \\
Mean & -1.2 & 17.0 & 78.8 & 2906.8 & 6.2 & & - & 7.0 & 10.7 \\
\hline
\end{tabular}


rameters varied over the seasons of the year (Table 3). There were significant correlations between the outdoor and the indoor climates (Table 4). Increased outdoor temperature caused increased indoor temperature, decreased relative humidity and decreased concentration of carbon dioxide in the units $(p<0.001)$. Consequently, there was also a correlation between the indoor climatic parameters with one another resulting in decreased relative humidity and decreased concentration of carbon dioxide when the indoor temperature increased $(p<0.001)$. Hence, the air concentration of carbon dioxide was positively correlated to the relative humidity $(p<0.001)$. In contrast, no correlation was found between the air concentrations of ammonia and the other indoor climatic parameters, nor did the average air concentrations of ammonia vary with seasons.

Low outdoor or indoor temperature, high concentration of carbon dioxide ( $>3000 \mathrm{ppm})$ and high concentration of ammonia ( $>10 \mathrm{ppm})$ did not significantly increase the prevalences of the lung lesions registered at slaughter. Thus, no significant correlation between the climatic parameters (outdoors as well as indoors) and the prevalences of pneumonia or pleuritis registered at slaughter was found in this study.

\section{Investigation II (Herds $G$ and H)}

Table 2 shows that the prevalences of pleuritis were low $(<6 \%)$ in the investigated herds both before and during the study and there was no significant difference between the herds. Furthermore, no significant difference in prevalence of pneumonic lesions registered at slaughter was found during the investigation, $15.0 \%$ and $13.7 \%$ for herd $\mathrm{G}$ and herd $\mathrm{H}$, respectively. However, before the investigation there was a significant difference $(p<0.05)$ in the prevalence of pneumonic lesions registered at slaughter between herds $\mathrm{G}(21.1 \%)$ and $\mathrm{H}$ (11.7\%). The DWG was significantly higher $(\mathrm{p}<0.05)$ in herd $\mathrm{G}$ before $(833 \mathrm{~g} /$ day $)$ as well as during (788 g/day) the investigation period, compared with herd H (793 and 734 g/day, respectively).

On arrival, $22,5 \%$ of the pigs in herd $\mathrm{G}$ had antibodies to M.hyo. compared to $7,5 \%$ in herd G. As shown in Table 5, the number of pigs with antibodies to M.hyo. was significantly higher $(\mathrm{p}<0.05)$ in herd $\mathrm{G}$ compared to herd $\mathrm{H}$ at 3, 6 and 9 weeks after the arrival. Also the average absorbance levels were significantly higher $(\mathrm{p}<0.05, \mathrm{p}<0.01)$ in herd $\mathrm{G}$ at 6 and 9 weeks after arrival. In contrast, no significant differences in number of seropositive pigs, nor absorbance levels, were found between the herds during the last 6 weeks of the rearing period. At the end of the fattening period, practically all pigs in both herds had developed antibodies to M.hyo.

On arrival, the percentage of pigs with antibodies to A.pp. serotypes 2 and 3, respectively, was similar for both herds (Table 5). Later the number of seropositive pigs was significantly $(\mathrm{p}<0.05, \mathrm{p}<0.01)$ higher in herd $\mathrm{H}$ compared with herd G. Similarly, the average absorbance values were significantly higher $(\mathrm{p}<0.05-$ 0.001 ) in herd $\mathrm{H}$ during the second half of the rearing period.

The differences between the indoor climate of herds $\mathrm{G}$ and $\mathrm{H}$ are shown in Table 6. The temperature was significantly $(p<0.05)$ lower in herd $\mathrm{H}$ during the whole rearing period except 3 weeks after arrival. Further, the concentrations of carbon dioxide and ammonia were significantly $(\mathrm{p}<0.05, \mathrm{p}<0.01)$ higher in herd $\mathrm{H}$ during a major part of the rearing period. The relative humidity was significantly higher $(p<0.05)$ in herd $H$ compared to herd G from 3 to 9 weeks after arrival. However, during the late rearing period (weeks 12 and 15), the relative humidity was higher $(\mathrm{p}<0.05)$ in herd $\mathrm{G}$. No significant correlation was found between the indoor climatic factors and the lung lesions 
Table 4. The correlations between selected climatic factors in herds A-F measured over the year.

\begin{tabular}{lcccc}
\hline & $\begin{array}{c}\text { Outdoor } \\
\text { temperature }\end{array}$ & $\begin{array}{c}\text { Indoor } \\
\text { temperature }\end{array}$ & $\begin{array}{c}\text { Relative } \\
\text { humidity }\end{array}$ & $\mathrm{CO}_{2}$ \\
\hline Indoor temperature & $0.81^{* * *}$ & & & \\
Relative humidity & $-0.82^{* * *}$ & $-0.79^{* * *}$ & & \\
$\mathrm{CO}_{2}$ & $-0.80^{* * *}$ & $-0.53^{* * *}$ & $0.73^{* * *}$ & \\
$\mathrm{NH}_{3}$ & $-0.09^{\text {N.S. }}$ & $0.04^{\text {N.S. }}$ & $0.04^{\text {N.S. }}$ & $0.20^{\text {N.S. }}$ \\
\hline
\end{tabular}

N.S. $=$ Not significant, ${ }^{* * *}=\mathrm{p}<0.001$.

registered at slaughter. Nor was any relationship between the lung lesions recorded at slaughter and the antibody status to M.hyo. and A.pp. serotypes 2 and 3 found to be significant. Any relationship between the higher DWG and the higher indoor temperature and lower concentrations of carbon dioxide and ammonia in herd $\mathrm{G}$ compared with herd $\mathrm{H}$ was not ensured (Tables 2, 5 and 6).

\section{Discussion}

To draw general conclusions of the present investigations may not be proper due to the low number of herds investigated. However, the number of collected data from each herd investigated was proportionately large thus explaining the strong correlations $(p<0.001)$ obtained between several of the parameters measured.

Investigation I aimed to study the influence of outdoor temperature on parameters reflecting the indoor climate over the year in fattening units. As the integrated herds (A-F) all performed continuous production systems, the number and total weight of pigs in each fattening unit were similar throughout the study. A significant correlation between indoor temperature, air concentration of carbon dioxide and relative humidity was found. In contrast, air concentration of ammonia was not correlated to these indoor parameters. Despite presence of heating systems, the low outdoor temperatures during winter influenced the indoor parameters by decreasing the temperature and increasing the concentration of carbon dioxide and the relative humidity of the air in the units. This might reflect deficient heating systems and poor coordination between the heating and ventilation systems as previously suggested by Gustafsson et al. 1994. In that study, it was also confirmed that an increased concentration of carbon dioxide could be caused by a too low minimum ventilation rate and that imperfections regarding the control of the relative humidity were common.

Lung lesions caused by M.hyo. and A.pp. can be reduced by an improved indoor climate (Tielen \& Elbers 1988, Robertson 1993). A dose-response relationship $(\mathrm{p}<0.05)$ between lung diseases registered at slaughter and high air concentrations of ammonia and carbon dioxide has been shown in a study by Donham 1991. The prevalence of pneumonia was shown to increase when the concentration of ammonia exceeded $25 \mathrm{ppm}$, and the prevalence of pleuritis increased when the concentration of ammonia exceeded $29 \mathrm{ppm}$. In that study, there was no correlation between high concentration of carbon dioxide and the prevalence of pneumonia, but concentrations of carbon dioxide exceeding $2020 \mathrm{ppm}$ increased the prevalence of pleuritis. However, in another study (Baekbo et al. 1996), no differences in the prevalences of pneumonia or pleuritis recorded at slaughter were found 
Table 5. Number of pigs with antibodies and average absorbance levels of antibodies to Mycoplasma hyopneumoniae and Actinobacillus pleuropneumoniae serotypes 2 and 3 during the rearing period.

\begin{tabular}{|c|c|c|c|c|c|c|}
\hline \multicolumn{7}{|c|}{ Mycoplasma hyopneumoniae } \\
\hline \multirow{2}{*}{$\begin{array}{c}\text { Weeks after } \\
\text { arrival }\end{array}$} & \multicolumn{3}{|c|}{ No. of pigs with antibodies } & \multicolumn{3}{|c|}{ Average absorbance level } \\
\hline & Herd G & Herd $\mathrm{H}$ & Sign. & Herd G & Herd $\mathrm{H}$ & Sign. \\
\hline 0 & $9 / 40 \#$ & $3 / 40$ & N.S. & 0.34 & 0.24 & N.S. \\
\hline 3 & $13 / 40$ & $4 / 40$ & * & 0.47 & 0.25 & N.S. \\
\hline 6 & $18 / 40$ & $8 / 40$ & * & 0.75 & 0.42 & * \\
\hline 9 & $28 / 40$ & $19 / 40$ & * & 1.04 & 0.63 & $* *$ \\
\hline 12 & $31 / 40$ & $32 / 40$ & N.S. & 1.21 & 1.11 & N.S. \\
\hline 15 & $33 / 34$ & $37 / 39$ & N.S. & 1.35 & 1.28 & N.S. \\
\hline
\end{tabular}

Actinobacillus pleuropneumoniae serotype 2

\begin{tabular}{cccccccc}
\hline \multirow{2}{*}{$\begin{array}{c}\text { Weeks after } \\
\text { arrival }\end{array}$} & \multicolumn{3}{c}{ No. of pigs with antibodies } & & \multicolumn{3}{c}{ Average absorbance level } \\
\cline { 2 - 3 } \cline { 7 - 8 } & Herd G & Herd $\mathrm{H}$ & Sign. & & Herd G & Herd H & Sign. \\
\hline 0 & $4 / 40 \#$ & $4 / 40$ & N.S. & & 0.16 & 0.17 & N.S. \\
3 & $5 / 40$ & $5 / 40$ & N.S. & & 0.16 & 0.19 & N.S. \\
6 & $11 / 40$ & $22 / 40$ & $*$ & & 0.25 & 0.40 & $*$ \\
9 & $15 / 40$ & $27 / 40$ & $* *$ & & 0.34 & 0.54 & $*$ \\
12 & $21 / 40$ & $31 / 39$ & $*$ & & 0.40 & 0.61 & $* *$ \\
15 & $20 / 34$ & $34 / 39$ & $* *$ & & 0.34 & 0.66 & $* * *$ \\
\hline
\end{tabular}

Actinobacillus pleuropneumoniae serotype 3

\begin{tabular}{cccccccc}
\hline \multirow{2}{*}{$\begin{array}{c}\text { Weeks after } \\
\text { arrival }\end{array}$} & \multicolumn{3}{c}{ No. of pigs with antibodies } & & \multicolumn{3}{c}{ Average absorbance level } \\
\cline { 2 - 3 } \cline { 7 - 8 } & Herd G & Herd $\mathrm{H}$ & Sign. & & Herd G & Herd H & Sign. \\
\hline \multirow{2}{*}{0} & $9 / 40 \#$ & $7 / 40$ & N.S. & & 0.27 & 0.20 & N.S \\
3 & $12 / 40$ & $8 / 40$ & N.S. & & 0.27 & 0.27 & N.S. \\
6 & $17 / 40$ & $24 / 40$ & N.S. & & 0.36 & 0.49 & N.S. \\
9 & $22 / 40$ & $31 / 40$ & $*$ & & 0.45 & 0.67 & $*$ \\
12 & $31 / 40$ & $34 / 40$ & N.S. & & 0.56 & 0.80 & $* *$ \\
15 & $22 / 34$ & $37 / 39$ & $* *$ & & 0.48 & 0.89 & $* * *$ \\
\hline
\end{tabular}

\# = Number of positive pigs/number of tested pigs.

N.S. $=$ Not significant $, \quad *=p<0.05, \quad * *=p<0.01, \quad * * *=p<0.001$.

between fatteners reared in stables with low concentrations of ammonia and carbon dioxide ( 9 and $1500 \mathrm{ppm}$, respectively) compared to fatteners reared in stables with high concentrations of the gases (17 and 2600 ppm, respectively).
Corresponding to Donham 1991 and Baekbo et al. 1996, no relationship between the climatic parameters measured in Investigations I and II and the prevalences of pneumonia and pleuritis registered at slaughter were shown, although the concentrations of carbon dioxide in some of 
Table 6. The average of temperature, relative humidity and the concentrations of carbon dioxide and ammonia in the stables for herd G (April-July) and herd H (January-May).

\begin{tabular}{lcccccc}
\hline & \multicolumn{7}{c}{ Week after arrival } \\
\cline { 2 - 7 } & 0 & 3 & 6 & 9 & 12 & 15 \\
\hline Temperature (deg. C.) & & & & & & \\
Herd G & 20.5 & 19.4 & 22.4 & 23.4 & 24.3 & 28.1 \\
Herd H & 18.0 & 19.2 & 20.4 & 19.1 & 18.3 & 23.5 \\
Significance & $*$ & NS & $*$ & $*$ & $*$ & $*$ \\
Rel. humidity (\%) & & & & & & \\
Herd G & 73.3 & 66.7 & 43.3 & 58.3 & 66.7 & 67.5 \\
Herd H & 76.7 & 75.7 & 76.3 & 70.0 & 61.7 & 53.3 \\
Significance & N.S. & $*$ & $*$ & $*$ & $*$ & $*$ \\
Carbon dioxide (ppm) & & & & & & \\
Herd G & 3250 & 1083 & 1100 & 1417 & 1483 & 1300 \\
Herd H & 2933 & 2500 & 2267 & 2000 & 2300 & 1667 \\
Significance & N.S. & $*$ & $*$ & $*$ & $*$ & N.S. \\
Ammonia (ppm) & & & & & & \\
Herd G & 2.0 & 2.2 & 1.3 & 2.5 & 2.8 & 3.3 \\
Herd H & 9.0 & 3.7 & 1.7 & 3.7 & 5.0 & 6.3 \\
Significance & $* *$ & N.S. & N.S. & N.S. & $*$ & $*$ \\
\hline
\end{tabular}

N.S. $=$ Not significant $\quad *=\mathrm{p}<0.05 \quad * *=\mathrm{p}<0.01$.

the herds periodically reached $3-4000 \mathrm{ppm}$. However, it should be noticed that the concentrations of ammonia never exceeded $12 \mathrm{ppm}$ in any of the units. Possibly, ammonia is a larger risk factor for development of lung lesions than carbon dioxide. Experimental studies have shown that ammonia causes cellular damage to the respiratory lining (Johannesen et al. 1987) and reduces the bacterial clearance from the lungs (Drummond et al. 1978). The concentration of carbon dioxide appears to give more information about the air hygiene and the balance of the ventilation system than about the prevalence of lung lesions registered at slaughter (Gustafsson et al. 1994).

Obviously, also environmental parameters not measured in the present study, as well as other factors, are involved in the cause of lung diseases (Tuovinen et al. 1992). For instance, significant correlation between lung lesions and high concentrations of respirable dust in the stables has been reported (Donham 1991, Robertson 1993). Although dust concentrations were not measured in this investigation, it is notable that herd A and initially also herd B, according to a subjectively judgement, had high concentrations of dust in the air. In these herds, the prevalences of pleuritis registered at slaughter were also high $(>25 \%)$. Besides the climatic conditions, the presence of stress-creating factors like regrouping, transferring, overcrowding and a continuous production are important for development of diseases (Schultz 1985, Tielen \& Elbers 1988). Furthermore, stress may depress the immunological capacity of the pigs and pave the way for infections already present on herd basis (Rosendal \& Mitchell 1983, Artursson et al. 1989, Wallgren et al. 1993).

When comparing the indoor climates of herds $G$ and $H$, herd $G$ was found to have a climate better suited for growing of pigs. This fact may partly be explained by a better ventilation 
system and a higher outdoor temperature during the rearing period. Despite this, infections with M.hyo. were spread more rapidly in herd G than in herd $\mathrm{H}$. This indicates that the development of mycoplasmosis during the rearing period appears to be more dependent on the incidence of M.hyo. infections on arrival than on the climatic factors in the units. Hence, a strict batch production (all in, all out) by itself does not prevent the development of mycoplasmosis because specialized fattening producers purchase pigs from several piglet herds with different status regarding M.hyo.

However, pneumonia is a dynamic process and infections with M.hyo. gained during the early rearing period heal before slaughter, causing no registration on that occasion (Lannek \& Börnfors 1957, Noyes et al. 1990, Wallgren et al. 1994). Nevertheless, a poor climate may amplify infections with M.hyo. obtained during the early fattening period and contribute to secondary infections. Among secondary invaders, Pasteurella multocida appears to be dominating (Bölske et al. 1980). Regardless of presence of secondary invaders, infections with M.hyo. obtained during the late rearing period seldom heal before slaughter (Wallgren et al. 1994).

The number of pigs with antibodies to A.pp. serotypes 2 and 3, as well as the average absorbance levels of antibodies, were low during the first 3 weeks after arrival to the fattening units in both herds, indicating an initial low pathogen load. From week 6 after arrival and onwards, the number of seropositive pigs and the average absorbance levels of antibodies, rapidly increased in both herds. This increase was largest in herd $\mathrm{H}$. The poorer indoor climate may have facilitated the spread of infections with A.pp. in that herd. Still, both of the herds expressed low prevalences of pleuritis registered at slaughter $(<3 \%)$, which is in line with the relatively low mean absorbance value of antibodies to A.pp. found in both herds, $\mathrm{A}_{450}<1.00$ (Wallgren et al.
1994). Taken together, these findings indicate presence of, but no severe problems, with A.pp. Indeed, herds with high prevalences of pleuritis recorded at slaughter generally have mean absorbance values exceeding 1.50 (Beskow et al. 1989).

The lower DWG in herd $\mathrm{H}(<750 \mathrm{~g} /$ day $)$ might reflect subclinical infections with A.pp. in that herd. Indeed, Rohrbach et al. 1993 has reported that there is a higher rate of gain in uninfected pigs compared with that of those that seroconverted to A.pp. but without expressive signs of disease. Also Lundeheim (1988) and Straw et al. (1990) have showed that respiratory diseases caused by M.hyo. and A.pp. reduce the DWG in fatteners. As a recent report failed to ensure the relationship between air quality and productivity of pigs statistically (Baekbo et al. 1996), the need to minimize spread of infections appears to be obvious in order to improve the productivity of the pigs (Young et al. 1959, Caldwell et al. 1961, Jörgensen 1987, Wallgren 1994).

In conclusion, well functioning heating systems are necessary to improve the indoor climate, especially during periods of low outdoor temperature. The heating and ventilation systems ought to be balanced to avoid increased relative humidity and high concentration of carbon dioxide at low outdoor temperature. The measured climatic parameters had no influence of the lung lesions registered at slaughter. The Swedish registration model of pneumonia at slaughter (based on magnitude and activity of the lesion) may be of less value in finding the real correlation between infection caused by M.hyo. and the indoor climate. Further, the climatic factors may have a larger influence on the spread of a less contagious lung disease (A.pp.) compared to a more contagious disease (M.hyo.). Still, the productivity of the pigs probably reflects the sum of all infections and stress factors that the animals are exposed to. 


\section{Acknowledgements}

The authors wish to thank Per Jonsson and Nils Lundeheim for valuable discussions and critical reading of the manuscript and Maria Persson and Sigbrit Mattsson for skilful technical assistance. This study was supported by grants from The Swedish Board of Agriculture and The Swedish Farmers Foundation of Agriculture Research.

\section{References}

Artursson $K$, Wallgren $P$, Alm $G V$ : Appearance of interferon serum and signs of reduced immune function in pigs after transport and installation in a fattening farm. Immunol. and Immunopath. 1989, 23, 345-353.

Baekbo P, Pedersen P, Thomsen LK: Impact of air quality on respiratory diseases and productivity. Proc. I.P.V.S. 1996, 14, 522.

Beskow $P$, Norqvist $M$, Thafvelin $B$ : Åtgärder i norrländska svinbesättningar med hög prevalens lungslaktskador (Measures taken on Norrland pig farms with a high prevalence of lung diseases at slaughter). Sv. Vet. Tidning. 1991, 43, 703-708.

Beskow P, Robertsson JA, Söderlind O: Testing of remedial measures in fattening pig herds affected with subclinical infections of Actinobacillus pleuropneumoniae serotype 2. J. Vet. Med. B. 1993, 40, 549-558.

Beskow P, Söderlind O, Thafvelin B: Actinobacillus (Haemophilus) pleuropneumoniae infections in swine: Serological investigations and vaccination trials in combination with environmental improvements. J. Vet. Med. B. 1989, 36, 487-494.

Bölske G, Johansson KE, Strandberg ML, Bergström $K$ : Comparison of the cross-reactions to different Mycoplasma hyopneumoniae antigen preparations in ELISA. Zbl. Bakt., Suppl.1990, 20, 832-835.

Bölske G, Martinsson K, Persson N: The incidence of mycoplasma and bacteria from lungs of swine with enzootic pneumonia in Sweden. Proc. I.P.V.S., 1980, 6, 213.

Caldwell JD, Underdahl NR and Young GA: Swine repopulation. III. Performance of primary SPF pigs on farms. J. Am. Vet. Med. Assoc. 1961, 138, 141-145.

Christensen G, Mousing J: Diseases of swine, Respiratory system. In: Leman et al. (eds), Diseases of swine 7 th ed. Ames, Iowa. The Iowa State University Press. 1992, 138-162.
Donham KJ: Association of environmental air contaminants with disease and productivity in swine. Am. J. Vet. Res., 1991, 52, 1723-1730.

Drummond JG, Curtis SE, Simon J: Effects of atmospheric ammonia on pulmonary bacterial clearance in the young pig. Am. J. Vet. Res. 1978, 39, 211-212.

Gustafsson $G$, von Wachenfelt E, Jeppsson KH, Andersson $M$ : Investigations of the climate and environment in pig houses in northern Sweden 1986 and 1993. Swedish University of Agricultural Sciences, Dep. of Agricultural Biosystems and Technology, Lund, Sweden. 1994, Report 92.

Hurvell B, Söderlind O, Gunnarsson A, Annebäck M: The use of ELISA-test for screening infections in swine. Proc. World Vet. Congr.1983, 22, 179.

Johannesen $U$, Erwerth $W$, Menger $S$, Neuman $R$, Mehlhorn $G$, Schimmel D: Experimental studies on effects of chronic aerogenous toxic gas stress on unweaned piglets with ammonia of varying concentrations. 3. Light- and electronmicroscopic studies on the pathology and pathogenesis of chronic aerogenous ammonia damage to the respiratory apparatus of the piglet. J. Vet. Med. B. 1987, 34, 260-273.

Jörgensen $B$ : Epidemiologiske analyser af sygdomsdata fra svinavlens Forsöksstationer (Epidemiological analysis from data of diseases obtained from the breeding socity's test stations). Dansk Vet. Tidsskr. 1987, 70, 209-219.

Lannek $N$, Börnfors $S$ : Immunity to enzootic pneumonia in pigs following recovery from the disease. Nord., Vet.-Med. 1957, 9, 91-98.

Lundeheim $N$ : Health disorders and growth performance at a Swedish pig progeny testing station. Acta Agric. Scand. 1988, 38, 77-88.

Nicolet J: Diseases of swine, Actinobacillus pleuropneumoniae. In: Leman et al. (eds), Diseases of swine 7 th ed. Ames, Iowa. the Iowa State University Press. 1992, 401-408.

Noyes EP, Feeney DA, Pijoan C: Comparison of the effect of pneumonia detected during lifetime with pneumonia detected at slaughter on growth in swine. J. Am. Vet. Med. Assoc., 1990, 197, 10251029.

Robertson JF: Dust and ammonia concentrations in pig housing: The need to reduce maximum exposure limits. Livestock Environment IV. Int. Symp. Univ. of Warwick Coventry, England 6-9 July 1993, 4, 694-700.

Rohrbach BW, Hall RF, Hitchcock JP: Effect of subclinical infection with Actinobacillus pleurop- 
neumoniae in commingled feeder swine. J. Am. Vet. Med. Assoc. 1993, 202, 1095-1098.

Rosendal S, Mitchell WR: Epidemiology of Haemophilus pleuropneumoniae infection in pigs: A survey of ontario pork producers, 1983: Can. J. Comp. Med., 47, 1-5.

Ross RF: Diseases of swine, Mycoplasmal diseases. In: Leman et al. (eds), Diseases of swine 7th ed. Ames, Iowa. the Iowa State University Press. 1992, 537-543.

Schultz R: Haemophilus Pleuropneumoniae of swine: Prevalence, treatment, control and prevention. Haemophilus Pleuropneumonia Compendium. Ann. Meet. Am. Assoc. Swine Practioners March 24-26, 1985, Des Moines, Iowa, 34-38.

Straw BE, Shin SJ, Yaeger AE: Effect of pneumonia on growth rate and feed efficiency of minimal disease pigs exposed to Actinobacillus pleuropneumoniae and Mycoplasma hyopneumoniae. Prev. Vet. Med. 1990, 9, 287-294

Tielen MJ, Elbers AR: Experiences with integrated chain control (ICC) for pig production in the Netherlands. Proc. Int. Congr. on Anim. Hyg. 1988, 6, 227-231.

Tuovinen VK, Gröhn YT, Straw BE, Boyd RD: Feeder unit environmental factors associated with partial carcass condemnations in market swine. Prev. Vet. Med. 1992, 12, 175-195.

Wallgren P: The importance of diseases for daily growth of pigs. Proc. Nord. Vet. Congr. 1994, 17, 106-110.

Wallgren P, Artursson K, Fossum C and Alm GV: Incidence of infections in pigs bred for slaughter revealed by elevated serum levels of interferon and development of antibodies to Mycoplasma hyopneumoniae and Actinobacillus pleuropneumoniae. J. Vet. Med. B. 1993, 40, 1-12.

Wallgren P, Beskow P, Fellström C, Renström L: Porcine lung lesions at slaughter and their correlation to the incidence of infections with $\mathrm{Myco}$ plasma hyopneumoniae and Actinobacaillus pleuropneumoniae During the Rearing Period. J. Vet. Med. B. 1994, 41, 441-452.
Wallgren P, Bölske G, Fossum $C$ : In vitro stimulation of antibody production to Mycoplasma hyopneumoniae by porcine peripheral blood mononuclear cells. Vet. Microbiol. 1992, 32, 363-374.

Young GA, Underdahl NR, Sumption LJ, Peo ER, Olsen LS, Kelly DB, Hudman DB, Caldwell JD and Adams CH: Swine population. I. Performance within a "disease-free" experiment station herd. J. Am. Vet. Med. Assoc. 1959, 134, 491-496.

\section{Sammanfattning}

Samband mellan utvalda klimatfaktorer $i$ slaktsvinsstall och deras betydelse för utvecklingen av luftvägsinfektioner hos svin.

I 6 integrerade besättningar med kontinuerlig produktion i slaktsvinsavdelningarna studerades klimatparametrarnas inbördes relation samt miljöns inverkan på registreringen av lungskador i samband med slakt. Likaså studerades i 2 specialiserade slaktsvinsbesättningar med strikt omgångsproduktion miljöns inverkan på spridningen av Mycoplasma hyopneumoniae och Actinobacillus pleuropneumoniae (serotyp 2 och 3) samt på tillväxten.

Det påvisades ett positivt samband mellan utomhustemperaturen och inomhustemperaturen. Den relativa fuktigheten och koncentrationen av koldioxid i stallarna var negativt korrelerade till utomhustemperaturen. Dessa inomhusparametrar var analogt inbördes relaterade till varandra. Stalluftens koncentrationen av ammoniak var ej korrelerad till någon av ovanstående parametrar.

Inget samband kunde påvisas mellan uppmätta inomhusparametrar och prevalensen av pneumonier och pleuriter registrerade vid slakt.

Snabbheten i spridning av Mycoplasmosa hyopneumoniae föreföll mer beroende av grisarnas antikroppsstatus vid ankomsten än på stallklimatet. I motsats till detta indikerades ett samband mellan utveckling av den subklinska/kroniska formen av $A c t i-$ nobacillus pleuropneumoniae infektion och klimatparametrarna. Inflytandet av dessa klimatparametrar på den dagliga tillväxten kunde inte fastställas.

(Received October 29, 1996; accepted October 20, 1997).

Reprints may be obtained from: P. Beskow, Swedish Animal Health Service, Fällforsselet 2, S-911 91 Vännäs, Sweden (Fax.: +46 935 31006) or from P. Wallgren, National Veterinary Institute, Box 7073, S-750 07 Uppsala, Sweden (Fax.: +46 18 309162). 